\title{
A new species of Euophrys (Aranei: Salticidae) from Israel
}

\section{Новый вид пауков рода Еиорьrys (Aranei: Salticidae) из Израимя}

\author{
Yuri M. Marusik \\ Ю.М. Марусик
}

Institute for Biological Problems of the North RAS, Portovaya Str.18, Magadan, 685000 Russia. E-mail: yurmar@mail.ru Институт биологических проблем Севера, ДВО РАН, Портовая 18, Магадан 685000 Россия.

Department of Zoology \& Entomology, University of the Free State, Bloemfontein 9300, South Africa.

KEY WORDS: Araneae, jumping spider, Negev.

КЛЮЧЕВЫЕ СЛОВА: Araneae, паук-скакунчик, пустыня Негев.

ABSTRACT. A new species, Euophrys friedmani sp.n., is described based on both sexes from the western Negev Desert. It is smallest of the Mediterranean Euophrys species. The male of the new species has very large base of embolus and lacks a retrolateral tibial apophysis. The female differs from all congeners by very long copulatory ducts forming about 4 loops. A small note is provided for E. gambosa (Simon, 1868) about size of its males.

How to cite this article: Marusik Yu.M. 2019. A new species of Euophrys (Aranei: Salticidae) from Israel // Arthropoda Selecta. Vol.28. No.4. P.562-566. doi: 10.15298/arthsel. 28.4.09

РЕЗЮМЕ. Описан новый пауков-скакунчиков, обитающий в западной части пустыни Негев Euophrys friedmani sp.n. Это наиболее мелкий представитель рода по меньшей мере в Средиземноморье. Самцы этого вида имеют непропорционально большое основание эмболюса, лишены отростка голени, а самки отличаются очень длинными копулятивными каналами образующими 4 петли. Кратко обсуждается размер самцов E. gambosa (Simon, 1868).

\section{Introduction}

Euophrys C.L. Koch, 1834 seems one of the largest genera of the family with 106 named species [WSC, 2019]. It was not split by Prószyński [Prószyński et al., 2018] like other species rich genera of Salticidae like Evarcha Simon, 1902, Myrmarachne MacLeay, 1839, Pseudicius Simon, 1885, Yllenus Simon, 1868, etc. Although the species assigned to the genus are known from all biogeographical realms, it seems that genus is restricted to the Holarctic and Africa only. Prószyński et al. [2018] doubted that all illustrated Euophrys species from South America and Vietnam belonged in that genus. Euophrys is well studied in the western Palaearctic and especially in the eastern Mediterranean. There are two monographic works dealing Salticidae of Greece [Metzner, 1999] and the Levant [Prószyński, 2003] where all Euophrys species occurring in these regions are revised. Although salticid fauna of Israel has been studied in detail a new species was found in two nearby localities in the Negev Desert. Description of this new species is a main goal of this paper.

\section{Material and methods}

Photographs were taken using an Olympus SZX16 stereomicroscope with a Canon-7D camera and prepared using Zerene Stacking software. Scanning electron micrographs were made using the SEM JEOL JSM-5200 scanning microscope at the Zoological Museum, University of Turku, Finland. Illustrations of the epigyne were made after maceration in a $20 \%$ potassium hydroxide aqueous solution and exposure for a few minutes in an alcohol/water solution of Chlorazol Black. Epigynes were photographed on slides with either an Olympus SZX16 or an Olympus BH-2. Measurements were made to an accuracy of $0.01 \mathrm{~mm}$. Lengths of leg and palp segments were measured on the dorsal side, from the midpoint of the anterior margin to the midpoint of the posterior margin. The sequence of the segment measurements is given for legs I-IV as follows: total length (femur + patella + tibia + metatarsus + tarsus), while for palp it is presented in the following order: total length (femur + patella + tibia + tarsus/ cymbium). All measurements are given in millimetres. Abbreviations used in text are as follows: ALE anterior lateral eye, AME — anterior median eye, PLE - posterior lateral eye.

Material treated here will be deposited in the following institutions: MMUE - the Manchester Museum of the University of Manchester, UK; SMNH - Steinhardt Museum of Natural History, Tel Aviv University, Israel; ZMMU the Zoological Museum of Moscow University, Moscow, Russia.

\section{Taxonomic survey}

Euophrys friedmani sp.n. Figs 1-3, 6-11, 13-21.

TYPES. Holotype $\sigma^{7}$ and allotype $q$ (SMNH), ISRAEL, Negev, env. Be'er Milka, $320 \mathrm{~m}, 30^{\circ} 56^{\prime} \mathrm{N} 34^{\circ} 24^{\prime} 10^{\prime \prime} \mathrm{E}$, wadi, tamarix 

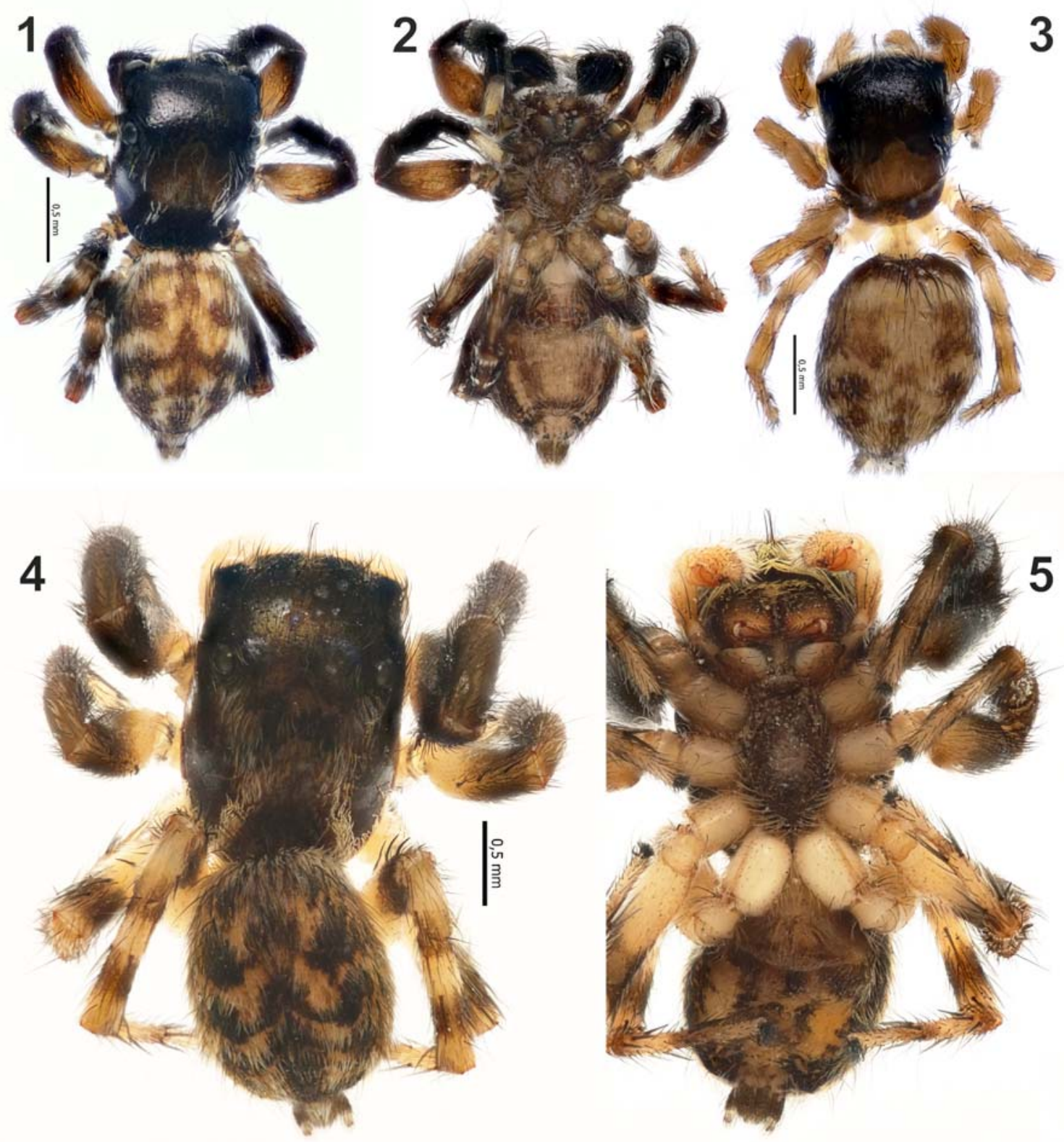

Figs 1-5. General appearance of Euophrys friedmani sp.n. (1-3) and E. gambosa (4-5). 1, 4 - male, dorsal; 2, 5 - male ventral; 3 female, dorsal. All specimens in the same scale $=0.5 \mathrm{~mm}$.

Рис. 1-5. Внешний вид Euophrys friedmani sp.n. (1-3) и E. gambosa (4-5). 1, 4 - самец, сверху; 2, 5 - самец, снизу; 3 самка, сверху. Все фотографии в одном масштабе $=0,5$ мм.

litter sifting \& hand picking, 12.03.2019 (Yu.M. Marusik). Paratypes $10^{7} 3$ 우 (ZMMU), 1 O 4 우 1 juv (SMNH), same data as for holotype; $50^{\top} O^{\top} 1$ subadult $O^{\top}, 2$ 우, 1 subadult + (MMUE) ISRA-

$\mathrm{EL}$, Negev, near Ashlaim, $336 \mathrm{~m}, 30^{\circ} 58^{\prime} \mathrm{N} 34^{\circ} 38^{\prime} 54.1^{\prime \prime} \mathrm{E}$, sifting of thick seed litter under grass and under tamarix, 12.03.2019 (Yu.M. Marusik).

ETYMOLOGY. The species is named after my colleague and friend Ariel-Leib-Leonid Friedman (ליאוניד•פרידמ) from Tel Aviv University, who organized field trip to the Negev Desert.

DIAGNOSIS. The new species differs from all congeners occurring in the Mediterranean Region by its minute size, $2.47 \mathrm{~mm}$ ( $v s$. total length $>4 \mathrm{~mm}$ ), embolus base longer than $1 / 2$ of the bulb length (vs. embolus base shorter than $1 / 2$ of bulb length), lack of a tibial apophysis (vs. present, exception E. gambosa (Simon, 1868)) and a very long copulatory duct forming 4 coils (loops) (vs. copulatory ducts with 3 loops or fewer). Male palp of E. friedmani sp.n. is similar to that in E. omnisupertes Wanless, 1975 due to the large embolic base, larger than $1 / 2$ of the bulb, however embolic base in new species covers entire anterior part of the tegulum vs. only antero-prolateral. Epigyne of the new species resembles those of E. leipoldti Peckham et Peckham, 1903 from South Africa, however it differs by having globular receptacles (vs. bean shaped), converging copulatory ducts 

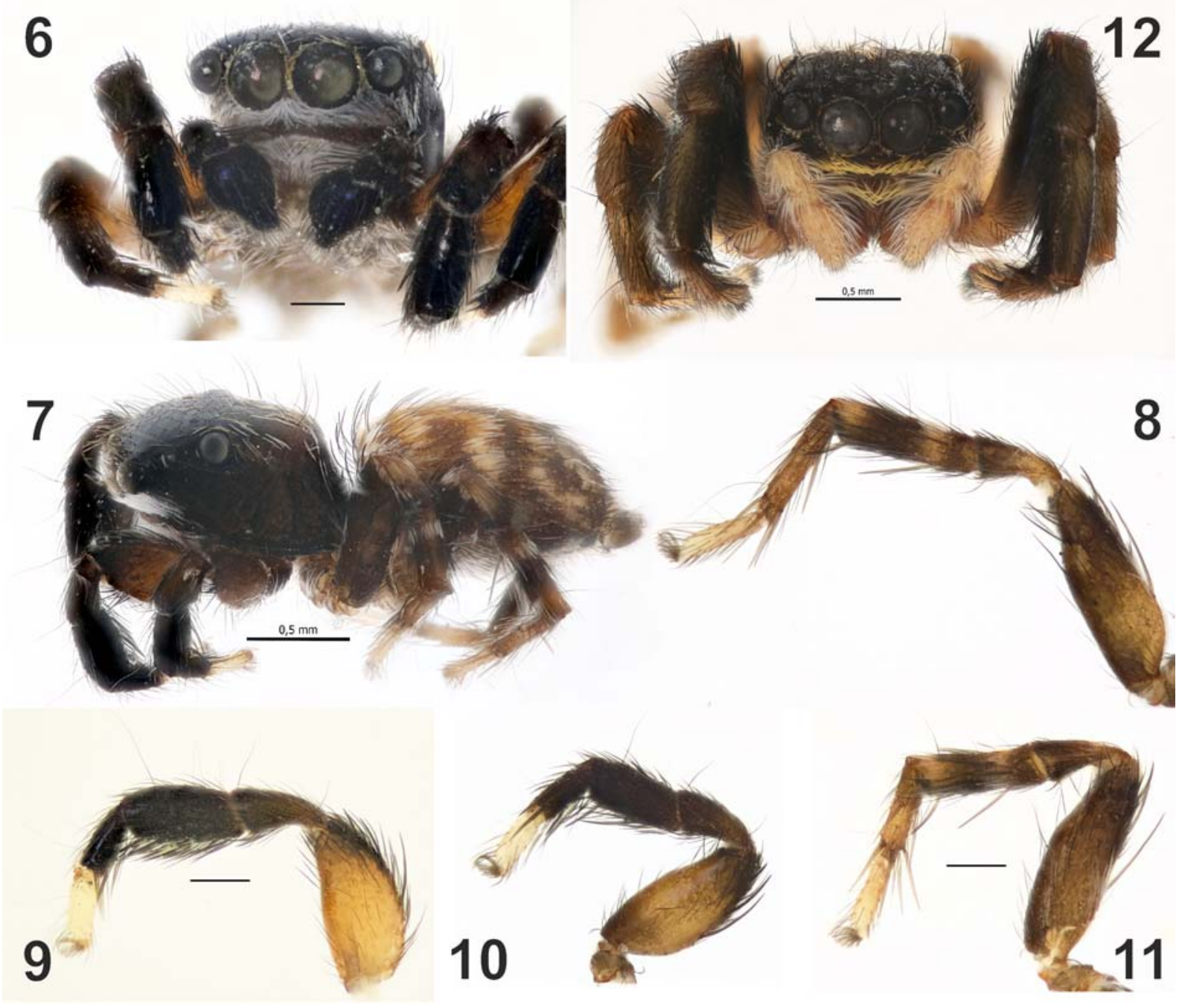

Figs 6-12. Males of Euophrys friedmani sp.n. (6-11) and E. gambosa (12). 6, 12 - prosoma, frontal; 7 - habitus, lateral; 8 - leg IV, anterior; 9 - leg I, anterior; 10 - leg II, anterior; $11-$ leg III, anterior. Scale $=0.2 \mathrm{~mm}$ if not otherwise indicated.

Рис. 6-12. Самцы Euophrys friedmani sp.n. (6-11) и E. gambosa (12). 6, 12 - головогрудь, спереди; 7 - внешний вид, сбоку; 8 нога IV, спереди; 9 - нога I, спереди; 10 - нога II, спереди; 11 - нога III, спереди. Масштаб 0,2 мм если не указано иначе.

forming 4 loops ( $v s$. diverging and having 3 loops of copulatory ducts). Male palps differ by absence (new species) or presence (E. omnisupertes) of tibial apophysis.

COMMENTS. The new species differs significantly from the generotype, E. frontalis (Walckenaer, 1802), by its much smaller size, presence of a dorsal abdominal scutum, lack of tibial apophysis in male palp, type of abdominal pattern, and very large embolus. It can not be placed in Talavera Peckham et Peckham, 1909, a genus in which all species are minute and male palps are lacking tibial apophysis, because Euophrys friedmani sp.n. has a very long and coiled embolus and copulatory ducts ( $v s$. short and not coiled) and the spermophor makes a transverse loop typical for Euophrys (vs. a longitudinal loop). Most likely E. friedmani sp.n. deserves the status of a separate genus.

DESCRIPTION. Male (holotype). Total length 2.47 . Carapace 1.19 long, 0.83 wide, 0.61 high. Ocular area 0.5 long, anterior and posterior width 0.86, AME 0.24, ALE 0.16 , PLE 0.15; clypeus 0.07 high, chelicera 0.31 long.
Abdomen 1.03 long, 0.78 wide. Scutum with indistinct margins, about $1 / 2$ of abdomen length. Live specimens look black like Chalcoscirtus, in alcohol carapace almost black, abdomen with distinct pattern. Clypeus with wide white band formed by setae and dark brown marginal band lacking setae, margin with stripe of white setae directed ventrally; eyebrows yellowish. Legs I and II (Figs 9-10) with contrasting pattern, tarsi yellow, metatarsi-patellae black, dorsoanterior part of femora black, lateral sides yellowish or light brown, tibia I spineless with brush of long and black setae ventrally; legs III and IV (Figs 8, 11) less contrasting, with kind of annulation. Leg lengths: I $1.85(0.64,0.39,0.36,0.29$, $0.17)$; II $1.75(0.6,0.36,0.31,0.27,0.21)$; III 2.14 (0.74, $0.36,0.39,0.36,0.29)$; IV $2.4(0.74,0.36,0.5,0.46,0.34)$.

\begin{tabular}{|c|c|c|c|}
\hline \multicolumn{4}{|c|}{ Spination } \\
\hline$\sigma^{2}$ & $\mathrm{Fe}$ & $\mathrm{Ti}$ & Mt \\
\hline I & $\mathrm{d} 3$ & & v2-2 \\
\hline II & $\mathrm{d} 3 \mathrm{p} 2$ & v0-2 & v2-2 \\
\hline III & $\mathrm{d} 3 \mathrm{p} 1$ & $\mathrm{p} 2 \mathrm{r} 2 \mathrm{v} 2-0$ & v2-2 \\
\hline IV & $\mathrm{d} 3$ & $\mathrm{p} 2 \mathrm{r} 2 \mathrm{v} 2-0$ & v2 \\
\hline
\end{tabular}



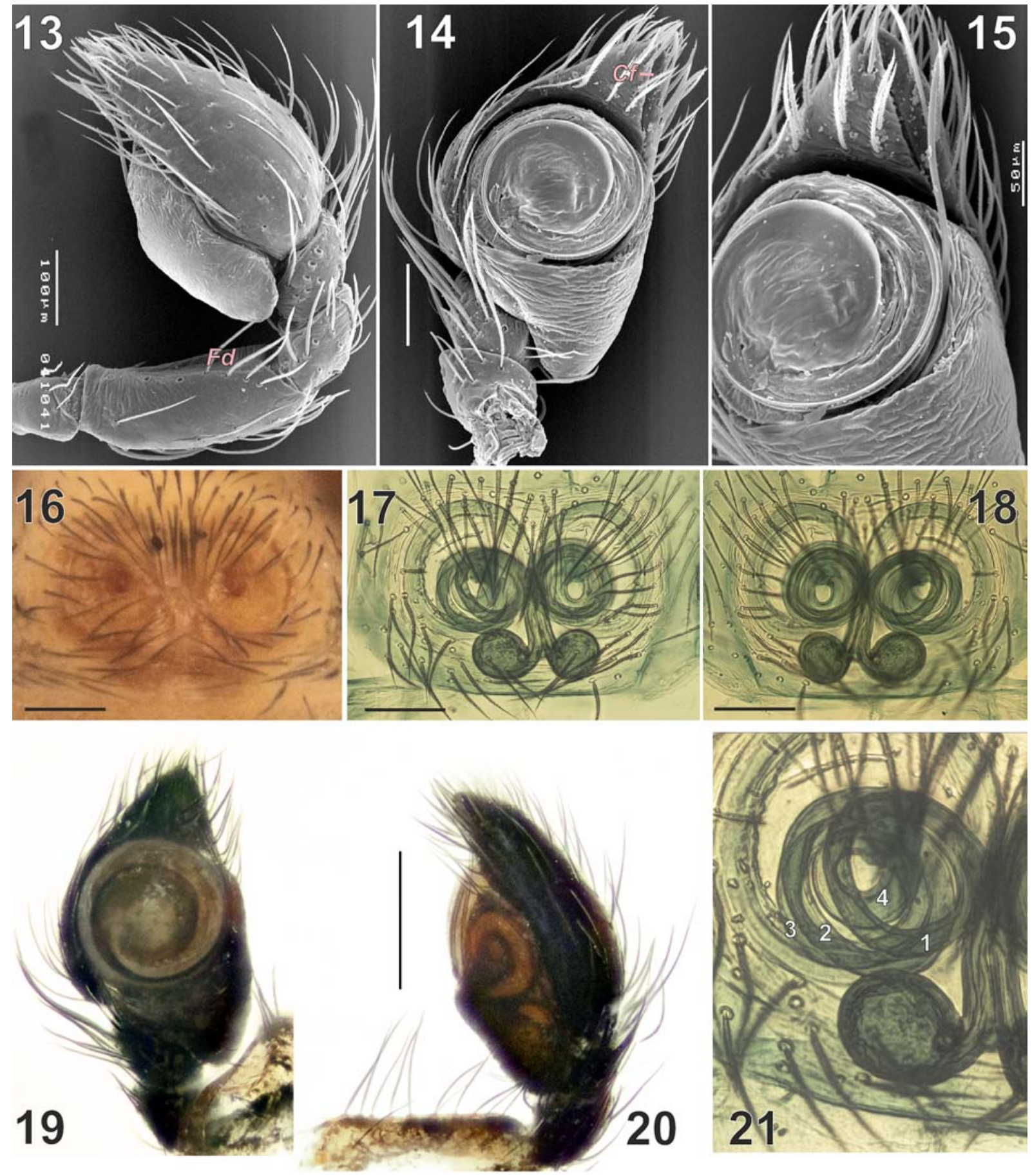

Figs 13-21. Copulatory organs of Euophrys friedmani sp.n. 13, 20 - male palp, retrolateral; 14, 19 - male palp, ventral; 15 - male palp, ventral, larger magnification; 16 - intact epigyne, ventral; $17-18$ - macerated epigyne, ventral and dorsal; 21 - right receptacle and copulatory duct. Scale $=0.2 \mathrm{~mm}$ if not otherwise indicated.

Abbreviations: $1-4-$ loops of copulatory ducts; $C f$ - cymbial fold; $F d$ - longitudinal depression of palpal femur.

Рис. 13-21. Копулятивные органы Euophrys friedmani sp.n. 13, 20 - пальпа самца, ретролатерально; 14, 19 — пальпа самца, снизу; 15 - пальпа самца, снизу на большем увеличении; 16 - интактная эпигина, снизу; 17-18 - мацерированная эпигина, снизу и сверху; 21 - правая рецептакула и копулятивный канал Масштаб 0,2 мм если не указано иначе.

Сокращения: 1-4 - петли копулятивных каналов; $C f$ - складка цимбиума; $F d-$ продольная впадина будра пальпы. 


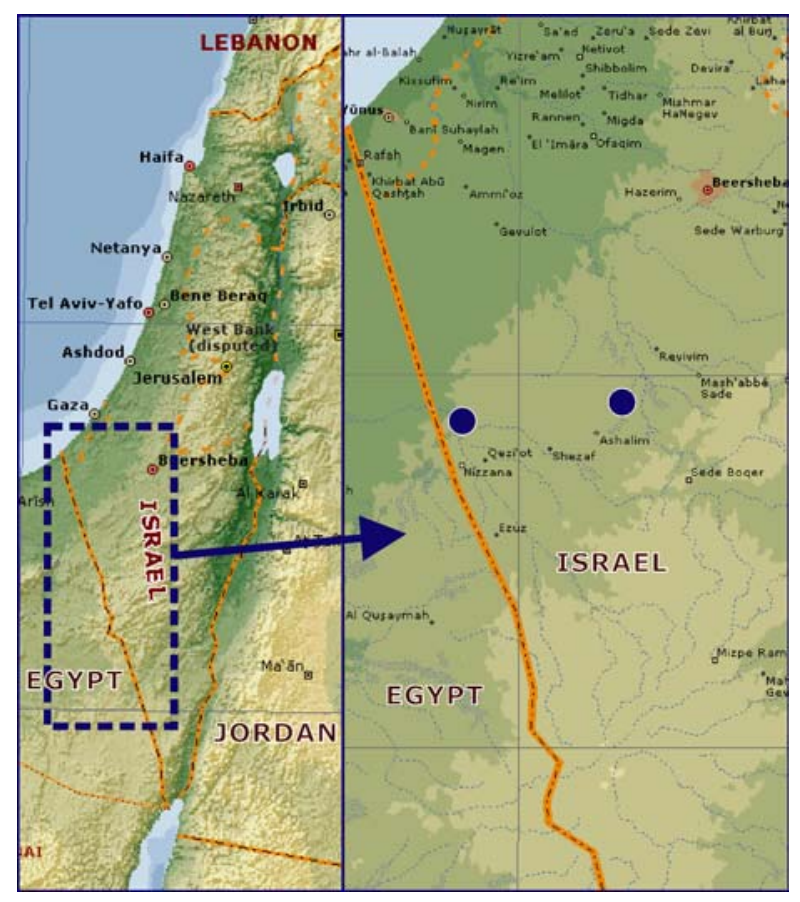

Fig. 22. Collecting localities of Euophrys friedmani sp.n.

Рис. 22. Места сбора Euophrys friedmani sp.n.

Palp as in Figs 6, 13-15, 19-20; almost black, with lighter femur; femur 1.1 times shorter than cymbium with ventral longitudinal depression $(F d$, Fig. 13); patella longer than tibia; tibia almost 2 times wider than long, apophysis absent; cymbium black with blue hue (Fig. 6), 1.25 longer than wide, tip about $1 / 3$ of cymbium length, retrolateral part of cymbial tip with deep fold ( $C f$, Figs 14-15), which seems to serve as sheath and conductor for tip of embolus; anterior half of the tegulum entirely covered with large embolus base, embolus forms 1.5 loops, tip filamentous, straight.

Female. Total length 2.74. Carapace 1.14 long, 0.83 wide, 0.5 high. Ocular area 0.5 long, anterior and posterior width 0.86, Abdomen 1.6 long, 0.83 wide; AME 0.24; ALE 0.17; PME 0.16; clypeus 0.07 high; chelicera 0.24 long. Coloration lighter than in male, with brown thoracic part of carapace. Abdominal pattern less distinct. Legs brown with poorly distinct annulations; patella and tibia I darker than other segments. Leg lengths: I 1.67 (0.54, 0.36, 0.31, 0.23, $0.23)$; II $1.6(0.5,0.34,0.29,0.24,0.23)$; III $1.95(0.64$, $0.34,0.36,0.31,0.3)$; IV $1.89(0.71,0.33,0.49,0-43,0.36)$.

\begin{tabular}{|c|c|c|c|c|}
\hline \multicolumn{5}{|c|}{ Spination } \\
\hline o & $\mathrm{Fe}$ & $\mathrm{Pt}$ & $\mathrm{Ti}$ & $\mathrm{Mt}$ \\
\hline I & d3 & & v3-3 & v2-2 \\
\hline II & d3 p1 & & v0-2 & v2-2 \\
\hline III & d3 p2(1) & r1 & $2 p$ v2- & $\mathrm{v} 2-2$ \\
\hline IV & d3 & r1 & $3 p$ & $3 p$ v2-1 \\
\hline
\end{tabular}

Epigyne as in Figs 16-18, 21; fovea 2 times wider than long, intact epigyne with distinct lateral margins and indistinct septum; macerated epigyne with a pair of round fovea; copulatory openings located in center of each fovea; receptacles globular, small, diameter slightly smaller that radius of fovea; copulatory ducts long forming about 4 coils around copulatory openings, diameter of copulatory duct subequal to 0.5 radius of receptacle.

DISTRIBUTION. Type locality only, Western Negev Desert.

\author{
Euophrys gambosa (Simon, 1868) \\ Figs 4-5, 12.
}

Attus gambosus Simon, 1868: 593, pl. 6, f. 7 (only face of unknow sex is illustrated, $\sigma^{\top}+$ ).

Euophrys gambosa: Metzner, 1999: 49, f. 14a-g (ơ).

Euophrys gambosa: Prószyński, 2003: 49, f. 163-170, 174176, 182-183, 188-189, 194-195 (ơo).

Euophrys gambosa: Prószyński et al., 2018: 37, f. 4C, 11H-L, 22A,D (O'O).

MATERIAL EXAMINED. $1 \sigma^{\top}$ (ZMMU), ISRAEL, Negev, env. Be'er Milka, $320 \mathrm{~m}, 30^{\circ} 56^{\prime} \mathrm{N} 34^{\circ} 24.166^{\prime} \mathrm{E}$, wadi, tamarix litter sifting \& hand picking, 12.03.2019 (Yu.M. Marusik).

COMMENTS. One male of this species was collected together with the holotype of E. friedmani sp.n. Males of these two species lack a tibial apophysis. Males differ in pattern and size. While checking literature I found that size of the males indicated in Metzner [1999] is smaller (total length 2.4, carapace 1.3) than in these from Israel (total length 3.19-4.23, carapace 1.65-2.25, after Prószyński [2003]. Specimen from the Negev fits the size indicated by Prószyński [2003]. Euophrys gambosa was described based on syntypes from Corsica, Spain, Sicily and Greece. Simon [1868] indicated male size as $5 \mathrm{~mm}$. It is possible that the type series includes more than one species.

\section{Acknowledgements}

I thank Leonid Friedman and Sergei Zonstein (Tel Aviv Univeristy) for organizing a field trip to the Negev Desert as well as Netta Dorchin (Tel Aviv Univeristy) for arranging all permissions. Special thanks are to Seppo Koponen and Ilari Sääksjärvi (Zoological Museum, University of Turku) for the permission to use museum facilities and arranging my stay in Turku. Dmitri Logunov and Galina Azarkina critically reviewed the manuscript and made valuable suggestion. The English of the final draft was kindly checked by Donald Buckle (Saskatoon, Saskatchewan, Canada).

\section{References}

Metzner H. 1999. Die Springspinnen (Araneae, Salticidae) Griechenlands // Andrias. Vol.14. S.1-279.

Prószyński J. 2003. Salticidae (Araneae) of the Levant // Annales Zoologici, Warszawa. Vol.53. No.1. P.1-180.

Prószyński J., Lissner J., Schäfer M. 2018. Taxonomic survey of the genera Euophrys, Pseudeuophrys and Talavera, with description of Euochin gen. n. (Araneae: Salticidae) and with proposals of a new research protocol // Ecologica Montenegrina. Vol.18. P.26-74.

Simon E. 1868. Monographie des espèces européennes de la famille des attides (Attidae Sundewall. - Saltigradae Latreille) // Annales de la Société Entomologique de France. Ser.4. T.8. P.1172, 529-726.

WSC. 2019. World Spider Catalog. Version 20.5. Natural History Museum Bern, online at http://wsc.nmbe.ch, accessed on 15.04.2019. doi: $10.24436 / 2$

Responsible editor K.G. Mikhailov 